\title{
PENGEMBANGAN PERANGKAT PEMBELAJARAN KOOPERATIF TIPE NHT BERBASIS LINGKUNGAN PADA MATERI POKOK SISTEM KOLOID
}

\author{
Syahruddin, Pince Salempa ${ }^{1}$, Jusniar ${ }^{2}$ \\ 1,2 Dosen PPs Pendidikan Kimia Universitas Negeri Makassar \\ Email: syahruddin_ch@yahoo.com
}

\begin{abstract}
ABSTRAK
Tujuan penelitian ini adalah untuk menjelaskan/mendeskripsikan proses pengembangan perangkat pembelajaran kooperatif tipe NHT berbasis lingkungan pada materi pokok sistem koloid dan untuk memperoleh perangkat pembelajaran kooperatif tipe NHT berbasis lingkungan pada materi pokok sistem koloid yang valid, praktis dan efektif. Pengembangan perangkat pembelajaran kimia sistem koloid pada SMK Negeri 6 Takalar berpedoman pada langkah-langkah pokok pengembangan pembelajaran model 4-D yang terbagi dalam empat tahapan yaitu: pendefenisian (define), perancangan (design), pengembangan (develop), dan penyebarluasan (disseminate). Perangkat pembelajaran yang dikembangkan yaitu RPP, BS, LKS dan THB divalidasi oleh 2 orang ahli dengan hasil penilaian berada pada kategori valid. Dari hasil analisis keterlaksanaan perangkat pembelajaran berada pada kategori tinggi dengan nilai rata-rata 4,09 dan memenuhi kriteria praktis. Aktivitas siswa, respon siswa, dan kemampuan guru mengelolah pembelajaran berada pada kategori tinggi serta tingkat keberhasilan dalam uji coba lapangan menunjukkan bahwa ketuntasan belajar siswa kelas XI TKJ SMK Negeri 6 Takalar adalah 83,33\% telah memenuhi kriteria keefektifan. Pada analisis respon guru terhadap perangkat pembelajaran diperoleh persentase sebesar $81,99 \%$ yang berarti respon positif guru berada pada kategori sangat tinggi. Berdasarkan kriteria yang digunakan untuk menilai perangkat pembelajaran yang dihasilkan yaitu kevalidan, keefektifan, dan kepraktisan, maka perangkat pembelajaran yang dikembangkan memenuhi kriteria valid, praktis, dan efektif.
\end{abstract}

Kata kunci: NHT, model 4-D, kooperatif, lingkungan, dan sistem koloid.

\begin{abstract}
The purpose of this study was to explain/describe the process of software development NHT type cooperative learning environment based on the subject matter of colloidal systems and to acquire the NHT type cooperative learning environment based on the subject matter of colloidal systems valid, practical and effective. Development of the learning device colloid chemistry system at SMK Negeri 6 Takalar based on the key steps in the development of 4-D model study were divided into four stages, namely: pendefenisian (define), the design (design), development (develop), and dissemination (disseminate). Developed learning tools that RPP, BS, LKS and THB validated by two experts with the results of the assessment were valid category. From the analysis of the feasibility study is in the high category with an average value of 4.09 and meet practical criteria. Student activities, student responses, and the ability to manage learning teacher at the high category and the level of success in field trials showed that mastery learning TKJ XI grade students of SMK Negeri 6 Takalar is $83.33 \%$ met the criteria of effectiveness. On analyzing the response of teachers to the learning device obtained a percentage of $81.99 \%$ which means the positive response of teachers are at very high category. Based on the criteria used to assess learning device that generated the validity, effectiveness and practicality, then the learning device developed meets the criteria for a valid, practical, and effective.
\end{abstract}

Keywords: NHT, 4-D models, cooperative, environmental, and colloidal systems. 


\section{PENDAHULUAN}

Ilmu kimia merupakan salah satu cabang ilmu pengetahuan yang begitu besar manfaatnya dalam pembangunan di berbagai bidang, oleh karena itu diperlukan peningkatan kualitas pembelajaran kimia di sekolah melalui pendekatan-pendekatan khusus sehingga diperoleh hasil belajar yang lebih optimal.

Proses belajar mengajar kimia dimana guru sebagai pengajar dan siswa sebagai subjek belajar dituntut adanya interaksi yang dapat melibatkan siswa belajar aktif dalam memperoleh pengetahuan. Dengan aktifnya siswa dalam pembelajaran, maka siswa dapat memahami konsep-konsep kimia yang sedang dipelajari sehingga dapat meningkatkan hasil belajar kimia.

Guru sebagai tenaga pendidik di sekolah dituntut untuk berperan menjadi seseorang yang menciptakan pembelajaran yang dapat meningkatkan peran serta siswa dalam pembelajaran. Guru sebagai pengelola pembelajaran memiliki tugas yaitu: merencanakan, mengatur, mengarahkan dan mengevaluasi (Sa'ud \& Makmun, 2005). Untuk itu, guru dalam melaksanaan proses pembelajaran perlu membuat keputusankeputusan misalnya metode dan model apa yang harus digunakan, alat-alat apa yang dibutuhkan untuk membantu siswa untuk mencapai tujuan yang telah ditetapkan. Model dan perangkat pembelajaran adalah dua hal yang yang sangat penting dan saling berkaitan yang harus mampu mengoptimalkan motivasi belajar siswa, membuat siswa terlatih belajar secara mandiri sehingga proses pembelajaran menjadi efektif. Model pembelajaran yang diterapkan dalam proses belajar mengajar sangat berpengaruh terhadap keberhasilan siswa dalam memahami materi yang disampaikan oleh guru.

Salah satu pembelajaran yang dapat meningkatkan hasil belajar dan aktifitas siswa adalah pembelajaran kooperatif. Melalui pembelajaran kooperatif maka dapat terjalin interaksi tidak hanya antara siswa dengan guru, akan tetapi juga terdapat interaksi antara siswa dengan siswa lainnya untuk membangun pengetahuan dan menyelesaikan masalah terkait materi yang dipelajari. Tujuan penting lainnya dari pembelajaran kooperatif adalah mengajarkan kepada siswa keterampilan kerja sama dan kolaborasi. Pembelajaran kooperatif menuntut siswa tidak hanya mempelajari materi saja, akan tetapi siswa diajarkan untuk saling berinteraksi sosial dalam memecahkan masalah bersama.

Pembelajaran kooperatif merupakan kegiatan pembelajaran yang dilakukan secara berkelompok, dimana setiap anggota kelompok bertanggung jawab terhadap kelompoknya masing-masing sehingga setiap anggota kelompok turut serta aktif dalam kelompoknya. Dengan mengetahui perannya dalam kelompok maka setiap siswa maka akan bersungguh-sungguh dalam kegiatan pembelajaran. Dengan menonjolkan interaksi dalam kelompok, model pembelajaran kooperatif dapat membuat siswa menerima siswa lain yang berkemampuan dan berlatar belakang berbeda (Suherman, 2001).

Pembelajaran kooperatif tipe NHT merupakan salah satu tipe pembelajaran kooperatif yang menekankan pada struktur khusus yang dirancang untuk mempengaruhi pola interaksi siswa dan memiliki tujuan untuk meningkatkan penguasaan akademik. Tipe ini dikembangkan oleh Kagen dalam Ibrahim (2000) dengan melibatkan para siswa dalam menelaah bahan yang tercakup dalam suatu pelajaran dan mengecek pemahaman mereka terhadap isi pelajaran tersebut.

NHT memiliki prosedur yang ditetapkan secara eksplisit untuk lebih banyak memberi kesempatan kepada siswa dalam berpikir, menjawab, dan saling membantu satu dengan yang lain (Arends, 2001). Pendapat ini juga didukung oleh Lie (2002) bahwa NHT lebih unggul dibanding dengan tipe yang lain karena tujuan kelompok bukan hanya menyelesaikan soalsoal yang diberikan tetapi juga memastikan bahwa setiap anggota kelompok menguasai dan memahami tugas atau soal-soal yang diterimnya. 
Pembelajaran kimia menggunakan model pembelajaran kooperatif tipe NHT dapat optimal untuk mencapai tujuan pembelajaran apabila proses pembelajaran dilengkapi dengan perangkat pembelajaran. Perangkat pembelajaran yang baik dapat membantu guru membelajarkan siswa untuk mencapai tujuan pembelajaran.

Kegagalan siswa dalam belajar tidak lepas dari keterkaitan antara siswa, guru, dan perangkat pembelajaran. Untuk itu perlu dilakukan pengembangan perangkat pembelajaran yang diharapkan mampu menunjang kesuksesan siswa dalam belajar. Pengembangan perangkat ini perlu dilakukan mengingat masih kurangnya perangkat pembelajaran yang dapat mengaktifkan siswa, meningkatkan kerjasama serta berorientasi pada lingkungan sekitar siswa. Perangkat yang ingin dikembangkan dalam penelitian ini adalah RPP, buku siswa, LKS, dan THB. Hal ini disebabkan karena keempat perangkat pembelajaran ini dapat mewakili komponen-komponen yang dibutuhkan dalam proses pembelajaran (Trianto, 2009).

Berdasarkan studi awal di SMK Negeri 6 Takalar ditemukan berbagai permasalahan dalam pembelajaran. Permasalahan tersebut diantaranya adalah kurang aktifnya siswa dalam pembelajaran karena kegiatan pembelajaran yang berlangsung di dalam kelas dikontrol dan dikendalikan langsung oleh guru, dan juga lebih menekankan pada proses pemindahan pengetahuan dari guru kepada siswa sehingga tidak menempatkan siswa sebagai pengonstruksi pengetahuan. Di samping itu, juga ditemukan masalah lain yaitu kemampuan bekerjasama antar siswa dalam pembelajaran belum terlaksana secara efektif. Faktor lain yang mempengaruhi rendahnya kualitas pembelajaran di SMK Negeri 6 Takalar adalah dari perangkat pembelajaran yang digunakan oleh guru. Perangkat-perangkat pembelajaran yang digunakan dari tahun ke tahun sama, tidak ada sama sekali usaha guru mengembangkan dan memperbarui perangkat pembelajarannya. Selain itu tidak tersedianya buku pegangan untuk siswa sebagai salah satu sumber belajar dan lembar kegiatan siswa yang dapat memberi tantangan pada siswa dalam pembelajaran, materi pelajaran tidak dikemas menyesuaikan kondisi siswa sehingga terkesan monoton dan memaksa siswa untuk berbuat sesuai apa yang diperintahkan oleh guru.

Beberapa perangkat pembelajaran dirancang kurang melibatkan keaktifan siswa dalam pembelajaran bahkan sangat sedikit yang mengintegrasikan pembelajaran dengan lingkungan. Sebagian guru masih kurang peduli dengan kualitas perangkat pembelajaran yang dibuatnya karena masih menganggap bahwa perangkat pembelajaran dibuat hanya untuk memenuhi persyaratan administrasi saja. Disamping itu banyak guru menggunakan perangkat pembelajaran seperti RPP dan LKS yang banyak diperjualbelikan tanpa memperhatikan terlebih dahulu kondisi siswa dan sekolahnya.

Sistem koloid merupakan salah satu materi pokok yang sangat erat hubungannya dengan kehidupan sehari-hari dan lingkungan siswa seperti air lumpur yang setelah diberikan tawas menjadi jernih, peristiwa awan, kabut, agar-agar, kosmetik dan lain sebagainya. Kenyataan ini, dapat mendorong rasa keingintahuan siswa untuk menggali lebih jauh tentang koloid. Sehingga siswa berperan aktif untuk berpikir, tidak hanya sebatas menerima penjelasan dari guru. Materi koloid juga sangat erat kaitannya di lingkungan siswa misalnya pencemaran lingkungan dapat di atasi dengan menggunakan pemahaman siswa tentang sifat-sifat koloid.

Berdasarkan uraian di atas, dipandang penting untuk mengembangkan perangkat pembelajaran kooperatif tipe NHT berbasis lingkungan. maka Peneliti tertarik untuk mengadakan penelitian yang berjudul Pengembangan Perangkat Pembelajaran Kooperatif Tipe NHT Berbasis Lingkungan Pada Materi Pokok Sistem Koloid. 
Berdasarkan uraian diatas maka dirumuskan pertanyaan penelitian ini sebagai berikut :

1. Bagaimanakah proses pengembangan perangkat pembelajaran kooperatif tipe NHT berbasis lingkungan pada materi pokok koloid?

2. Apakah perangkat pembelajaran kooperatif tipe NHT berbasis lingkungan pada materi pokok koloid yang dikembangkan dinyatakan valid, praktis, dan efektif?

\section{METODE PENELITIAN}

1. Jenis Penelitian

Penelitian ini adalah penelitian pengembangan atau Research and Develoment model $4 D$ yaitu mengembangkan perangkat pembelajaran kooperatif tipe NHT berbasis lingkungan pada materi sistem koloid yang meliputi Rencana Pelaksanaan Pembelajaran (RPP), Buku Siswa (BS), Lembar Kegiatan Siswa (LKS), dan Tes Hasil Belajar (THB).

2. Lokasi dan Subjek Penelitian

Penelitian ini dilaksanakan di SMK Negeri 6 Takalar pada semester genap tahun pelajaran 2014/2015. Subjek dalam penelitian ini adalah kelas XI jurusan Teknik Rekayasa dan Jaringan dengan jumlah siswa 30 orang sebagai subjek uji coba terbatas.

3. Analisis data

Data yang telah dikumpul dianalisis secara kuantitatif yang terdiri dari :

\section{Analisis Data Kevalidan Perangkat Pembelajaran}

Data hasil validasi perangkat pembelajaran merupakan penilaian yang dilakukan oleh para ahli terhadap draf perangkat pembelajaran yang dikembangkan 2. Analisis Data Kepraktisan Perangkat Pembelajaran

Pengamatan mengenai kepraktisan perangkat pembelajaran yang dikembangkan dapat dilihat dari pengamatan terhadap kemampuan guru dalam mengunakan perangkat pembelajaran yang dikembangkan melalui model kooperatif tipe NHT berbasis lingkungan di kelas. Instrumen yang digunakan adalah lembar observasi keterlaksanaan perangkat pembelajaran yang dikembangkan. Data yang diperoleh selanjutnya dianalisis untuk menentukan nilai rata-rata keterlaksananaan perangkat pembelajaran pada setiap pertemuan.

3. Analisis Data Keefektifan Perangkat Pembelajaran

Keefektifan perangkat pembelajaran ditinjau dari :
a. Aktivitas siswa
b. Analisis data respon siswa terhadap pembelajaran
c. Analisis data kemampuan guru mengelola pembelajaran
d. Tes hasil belajar

\section{HASIL DAN PEMBAHASAN}

a. Kevalidan

Perangkat pembelajaran yang telah disusun selanjutnya divalidasi oleh para ahli. Adapun hasil validasi perangkat pembelajaran disajikan pada tabel 1 .

Tabel 1. Hasil validasi perangkat pembelajaran

\begin{tabular}{|c|l||c|c||}
\hline No. & Perangkat pembelajaran & Penilaian & Ket \\
\hline \hline 1. & $\begin{array}{l}\text { Rencana pelaksanaan } \\
\text { pembelajaran (RPP) }\end{array}$ & 4,37 & V \\
\hline 2. & Buku siswa (BS) & 4,05 & V \\
\hline 3. & Lembar kerja siswa (LKS) & 4,05 & V \\
\hline 4. & Tes hasil belajar (THB) & 4,25 & V \\
\hline
\end{tabular}

Keterangan:

$\begin{array}{ll}1 \leq \mathrm{Va}<2 & \text { tidak valid } \\ 2 \leq \mathrm{Va}<3 & \text { kurang valid } \\ 3 \leq \mathrm{Va}<4 & \text { cukup valid } \\ 4 \leq \mathrm{Va}<5 & \text { valid } \\ \mathrm{Va}=5 & \text { sangat valid }\end{array}$

Dari hasil analisis data yang diperoleh maka perangkat pembelajaran yang dikembangkan dinyatakan valid.

b. Kepraktisan

Perangkat pembelajaran yang telah direvisi selanjutnya diujicobakan untuk mengetahui kepraktisannya. Kepraktisan perangkat pembelajaran dapat diperoleh melalui hasil pengamatan terhadap kemampuan guru dalam menggunakan perangkat pembelajaran melalui lembar observasi keterlaksanaan perangkat pembelajaran. Deskripsi masing-masing 
aspek keterlaksanaan perangkat pembelajaran oleh guru diuraikan pada tabel 2:

Tabel 2. Analisis keterlaksanaan perangkat pembelajaran

\begin{tabular}{|c||c||c|c|}
\hline No & \multicolumn{1}{|c|}{ Aspek yang dinilai } & Penilaian & Ket. \\
\hline 1. & Sintaks RPP & 4,08 & Tinggi \\
\hline 2. & Sistem Sosial & 4,16 & Tinggi \\
\hline 3. & Prinsip Reaksi Pendukung & 4,15 & Tinggi \\
\hline 4 & $\begin{array}{l}\text { Sistem } \\
\text { Perangkat Pembelajaran }\end{array}$ & 4,0 & Tinggi \\
\hline \multicolumn{2}{|c|}{ Rata-rata seluruh aspek } & 4,09 & Tinggi \\
\hline
\end{tabular}

Keterangan:

$\begin{array}{ll}1 \leq \mathrm{IO}<2 & \text { sangat rendah } \\ 2 \leq \mathrm{IO}<3 & \text { rendah } \\ 3 \leq \mathrm{IO}<4 & \text { sedang } \\ 4 \leq \mathrm{IO}<5 & \text { tinggi } \\ \mathrm{IO}=5 & \text { sangat tinggi }\end{array}$

Dari hasil analisis terhadap hasil pengamatan keterlaksanaan perangkat pembelajaran berada pada kategori tinggi yaitu 4,09 $(4 \leq \mathrm{IO}<5)$. Dengan demikian dapat disimpulkan bahwa keterlaksanaan perangkat pembelajaran telah memenuhi kriteria praktis.

c. Keefektifan

1. Aktivitas siswa

Dari hasil analisis data aktivitas siswa diperoleh $63,33 \%$ kategori sangat baik dan $36,67 \%$ kategori baik. Berdasarkan hasil analisis data aktivitas siswa menunjukkan bahwa lima kategori pengamatan aktivitas siswa terpenuhi

2. Respon siswa

Dari hasil analisis data respon siswa diperoleh siswa yang memberikan respon positif sebanyak $89,61 \%$ dan telah memenuhi kriteria keefektifan $(\geq 80 \%)$.

3. Pengamatan pengelolaan pembelajaran

Dari hasil analisis diperoleh skor ratarata untuk seluruh katogori yaitu 4,13 yang berada pada kategori baik $4 \leq \mathrm{NKG}<5$. Berdasarkan kriteria yang ditetapkan, maka dapat disimpulkan bahwa guru mampu mengelolah pembelajaran kimia dengan baik.

4. Ketercapaian tes hasil belajar siswa

Dari hasil analisis terhadap tes hasil belajar diperoleh siswa yang tidak tuntas sebanyak 5 orang dan yang tuntas sebanyak
25 orang dengan ketuntasan kelas sebesar $83,33 \%$.

Data tersebut menunjukkan bahwa secara klasikal, siswa memperoleh pemahaman yang baik terhadap materi yang disajikan dengan menggunakan perangkat pembelajaran kooperatif Tipe NHT berbasis lingkungan. Dengan demikian, perangkat pembelajaran kooperatif Tipe NHT berbasis lingkungan efektif digunakan pada pembelajaran sistem koloid. Walaupun secara klasikal dapat dinyatakan siswa tuntas belajar menggunakan perangkat pembelajaran kooperatif Tipe NHT berbasis lingkungan, namun secara perorangan masih ada siswa yang belum tuntas belajar bahkan ada beberapa siswa yang berada pada kategori rendah. Hal ini disebabkan siswa tersebut masih sulit mengubah kebiasaan belajarnya.

5. Respon Guru terhadap Perangkat Pembelajaran

Keefektifan perangkat pembelajaran dapat juga dilihat dari hasil penilaian guru SMK Negeri 2 Takalar terhadap perangkat yang disebarkan secara terbatas pada sekolah tersebut. Persentase secara keseluruhan dari perangkat pembelajaran sebesar 82,66\% artinya secara empirik, perangkat pembelajaran kooperatif tipe NHT berbasis lingkungan yang telah dikembangkan layak digunakan dalam membantu siswa untuk mencapai tujuan pembelajaran.

\section{KESIMPULAN}

Dari hasil penelitian pengembangan perangkat pembelajaran yang dilaksanakan maka dapat ditarik kesimpulan sebagai berikut:

1. Proses pengembangan perangkat pembelajaran kooperatif tipe NHT berbasis lingkungan yang terdiri dari Buku siswa, LKS, RPP dan THB dikembangkan menurut model pengembangan 4-D. Proses pengembangan dimulai dari analisis awal akhir, analisis siswa, analisis konsep, analisis tugas dan analisis tujuan, kemudian dilakukan penyusunan tes, 
pemilihan media, pemilihan format sampai diperoleh desain awal perangkat pembelajaran. Selanjutnya semua desain awal divalidasi oleh ahli, setelah berada pada kategori valid atau sangat valid lalu diujicobakan untuk mengetahui kepraktisan dan keefektifan, sehingga layak digunakan.

2. Kualitas perangkat pembelajaran kooperatif tipe NHT berbasis lingkungan pada materi pokok sistem koloid tergolong kategori valid, praktis, dan efektif.

\section{DAFTAR PUSTAKA}

Anonim. 2007. Petunjuk Teknis Pengembagan Silabus dan Contoh Model Silabus. Jakarta: BSNP.

Arends, Richard.2001. Learning to Teach. McGraw-Hill Companies, Inc.New York.

Firman, H, L. 1997. Kimia 1. Jakarta: Departemen Pendidikan dan Kebudayaan Balai Pustaka.

Hobri. 2009. Metodologi Penelitian Pengembangan (Developmental Research) Aplikasi Pada Penelitian Pendidikan Matematika. Jember : Universitas Jember.

Ibrahim, Muslimin. dkk. 2000. Pembelajaran Kooperatif .University Press. Universitas Negeri Surabaya.

2005. pembelajaran kooperatif. Universitas Negeri Surabaya. Surabaya.

Kauchak, P., dan Eeggen, D. 1993. Strategies for Teachers, Teaching Content and Thinking Skills. Allyn and Bacon Publisher. Boston.

Lago, R. G. M. 2007. Influence of Cooperative Learning on Chemistry Students Achievement, Self-Eficacy and Antitude. Liceo Journal of Higher Education Research, 5(1).

Lie, Anita. 2002. Cooperative Learning. Jakarta : PT. Gramedia Widiasarana Indonesia.
Multyaningsih, E. 2012. Metode Penelitian Terapan Bidang Pendidikan. Bandung: CV Alfabeta.

Patmawati. 2007. Peningkatan Hasil Belajar Matematika Melalui Model Pembelajaran Kooperatif Tipe Numbered Head Together Pada Siswa Kelas VII A SMP Negeri 33 Makassar. Skripsi FMIPA Universitas Negeri Makassar. Makassar.

Rahmawati, D., dkk. 2014. Penerapan Model Pembelajaran Kooperatif tipe Number Head Together Berbasis Eksperimen untuk Meningkatkan Keterampilan Proses Sains Siswa SMP. Unnes Physic Education Journal, 3(1), 40-45.

Sabara, E. 2011. Pengembangan Penuntun Praktikum Kimia Berorientasi Life Skills Siswa Kelas XI IPA Di SMA Negeri 1 Binamu Kabupaten Jeneponto. Tesis tidak diterbitkan. Makassar: UNM.

Sa'ud, S.U \& Makmun, S.A. 2005. Perencanaan Pendidikan Suatu Pendekatan yang Komrehensif. Bandung: Remaja Rosdakarya.

Slavin, Robert E. 1995. Cooperative Learning: Theory, Research and Practice.Second Edition. Allyn and Bacon Publisher. Boston.

Suherman, Erman. Dkk. 2001. Strategi Pembelajaran Matematika Komtemporer. JICA Univeritas Pendidikan Indonesia. Bandung.

Thiagarajan, S., dkk. 1974. Instructional Development for Training Teachers of Expectional Children. Minneapolis, Minnesota: Leadership Training Institute/Special Education, University of Minnesota.

Trianto.2007. Model-model Pembelajaran Inovatif Berorientasi Konstruktivistik. Jakarta:Prestasi Pustaka.
----------.2009. Mendesain Model Pembelajaran Inovatif-Progresif. Jakarta : Kencana Prenada Media Group.


---------.2011. Mendesain Model Pembelajaran Inovatif-Progresif. Ed ke-4. Jakarta : Kencana Prenada Media Group.

Warpala, W.S. 2008 .Jurnal Penelitian Dan Pengembangan Pendidikan, (online), Vol. 2, No. 2 (http://downloads.ziddu.com/downloa dfile, diakses 11 Januari 2015) 